\title{
New and rare fungus gnats for the fauna of Bulgaria (Diptera: Nematocera: Mycetophilidae)
}

\begin{abstract}
Aneliya Pavlova
Department of Zoology, University of Plovdiv "Paisii Hilendarski”, 24 Tsar Ivan Asen Street, 4000 Plovdiv, Bulgaria, aneliapav@gmail.com

http://zoobank.org/DC6BAD2C-BEAF-464D-A836-9F56D718159D

Abstract: The paper provides information about two newly recorded species for the fauna of Bulgaria: Docosia rohaceki Sevcik, 2006 and Leia graeca Bechev, 1997 and new localities for another two rare species in Bulgaria. Azana (A.) bulgarense Coher, 1995 is proposed as a synonym of Azana (A.) flavohalterata Strobl, 1909.
\end{abstract}

Keywords: Balkan Peninsula, Bulgaria, Mycetophilidae, new localities, new records, new synonym

\section{Introduction}

So far, 319 species of fungus gnats are known from the territory of Bulgaria (Bechev, 2006, 2010; Bechev \& Pavlova, 2012, 2016; Kurina \& Chandler, 2018; Pavlova, 2020; Pavlova \& Stojanova (in press)). As a result of our study, here we present the first records of two species in Bulgaria and an update on the distribution of two species that have been previously recorded in the country only from single localities.

\section{Material and methods}

Part of the material was collected within the framework of the project "Studies on biodiversity of model animal groups in Kermes Oak communities (Quercus coccifera L.), anthropogenic impact assessment and proposing protection measures" (Bulgarian National Science Fund No B-MU-1106/01) (Langourov \& Simov, 2006). The rest of the material is gathered by the author. Three sampling techniques were used: traps, tree traps - white coloured modified Moericke traps (Langourov, 2001; Langourov \& Simov, 2006), both filled with formalin or propylene glycol, and Townes

Received: 27 January 2020 • Editor: Mario Langourov type Malaise trap. The traps were changed each month. The chosen localities are in critically endangered Mediterranean habitats in Bulgaria (Figs 1-2): shrubs and low woods of the Kermes oak (Quercus coccifera) (Gussev, 2015; Langourov et al., 2012) and forests of Grecian juniper (Juniperus excelsa) (Tzonev \& Dimitrov, 2015).

The material is deposited in the author's collection and in the collection of the National Museum of Natural History, Sofia.

\section{Results and discussion}

List of records

Family Mycetophilidae

Subfamily Leiinae

Docosia rohaceki Sevcik, 2006

Examined material: Bulgaria: Western Rhodope Mts, Krichim, Izgoryaloto Gyune Reserve, N 42.0281; E 24.46926, $321 \mathrm{~m}$, collecting period: iii.2019, tree traps: 
Aneliya Pavlova

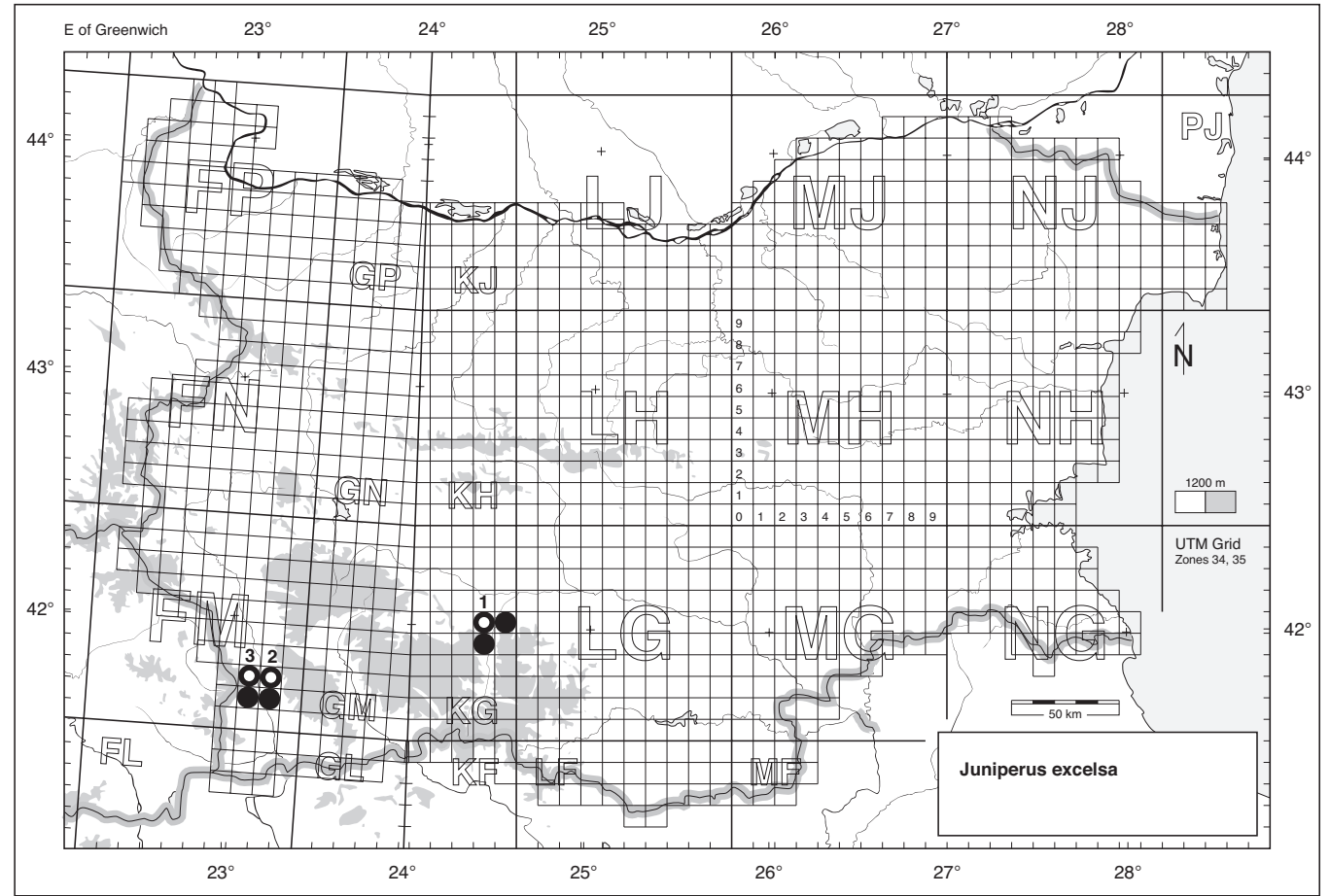

Fig. 1. Distribution of forest of Grecian juniper (Juniperus excelsa) after Tzonev \& Dimitrov (2015); [circle] - localities; [black and white circle] - studied areas: 1 - Izgoryaloto Gyune Reserve, 2 - 2 km south of Stara Kresna Village, 3 - Tisata Reserve.

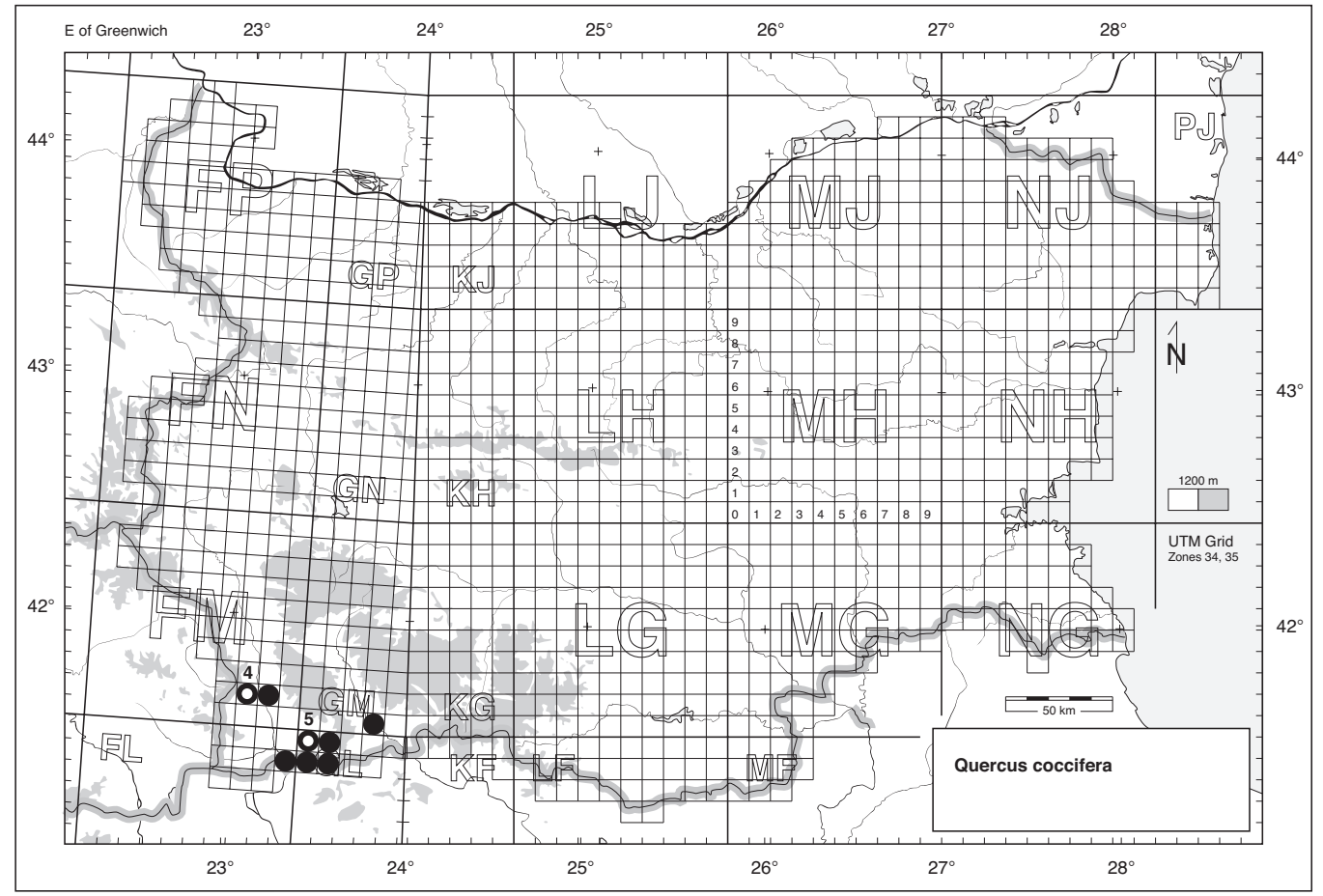

Fig. 2. Distribution of shrubs and low woods of Kermes oak (Quercus coccifera) after Gussev (2015) and Langourov et al. (2012); [circle] - localities; [black and white circle] - studied areas: 4 - 2 km south of Kamenitsa Village, 5 - St Iliya Peak, Kalimantsi Village. 


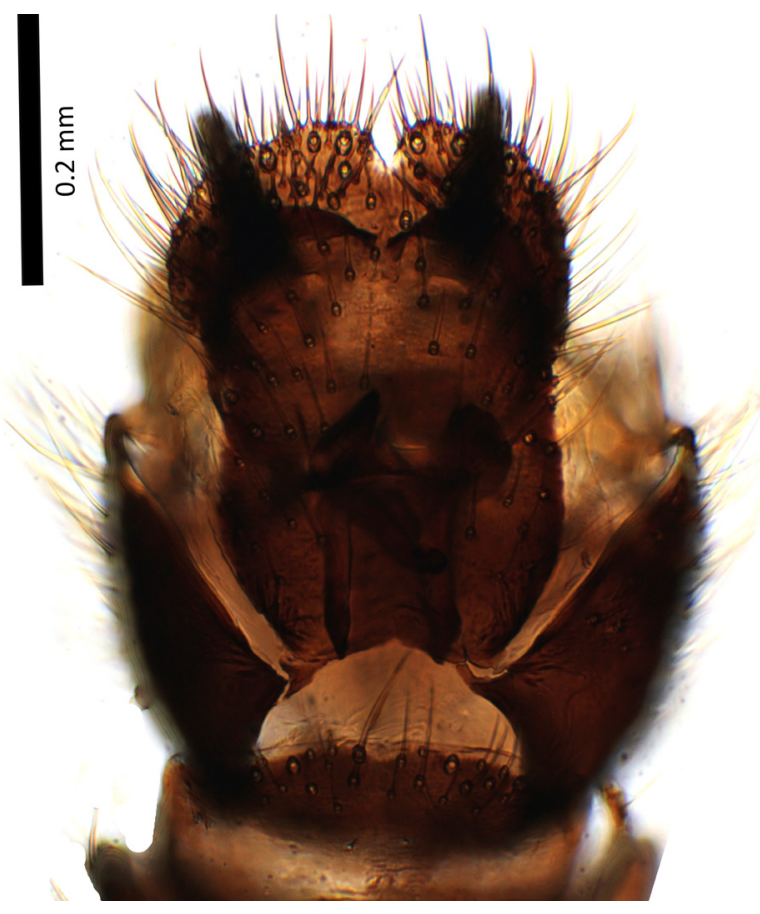

Fig. 3. Dorsal view of the male genitalia of a specimen of $D$. rohaceki from Bulgaria: Western Rhodope Mts, Krichim, Izgoryaloto Gyune Reserve, N 42.0281; E 24.46926, 321 m, iii.2019, tree traps, leg. A. Pavlova.

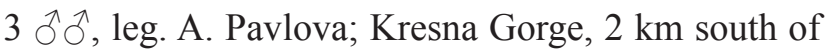
Stara Kresna Village, N 41.76257; E 23.16916, 203400 m, collecting period: iii. 2019, pitfall traps: 1 万, leg. A. Pavlova, collecting period: iv.2003, Malaise trap: 2 $\widehat{\partial}$, leg. M. Langourov; Alibotush Mts, Kalimantsi Village, St Iliya Peak, N 41.46001; E 23.49058, 440-510 m, collecting period: xi.2002, tree traps: 480 $\widehat{\widehat{\partial}} \widehat{\partial}$, leg. M. Langourov; collecting period: xii.2002, tree traps: $56 \widehat{\curvearrowright} \widehat{\jmath}$, leg. M. Langourov, K. Ivanov, N.

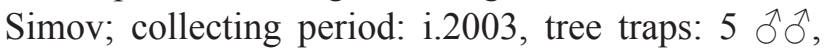
leg. S. Lazarov, N. Simov; collecting period: iv.2003, tree traps: 4 ô $\widehat{\jmath}$, leg. M. Langourov, S. Lazarov.

New species for the fauna of the Balkan Peninsula. Previously, it has been known only from Slovakia (Ševčík, 2006). This is the most south-eastern record for the species. Photo of male genitalia of the studied specimens is presented on figure 3 .

\section{Ectrepesthoneura ledenikiensis Bechev, 1988}

Material examined: Bulgaria: Kresna Gorge, $2 \mathrm{~km} \mathrm{~S}$ of Stara Kresna Village, geographic coordinates: N

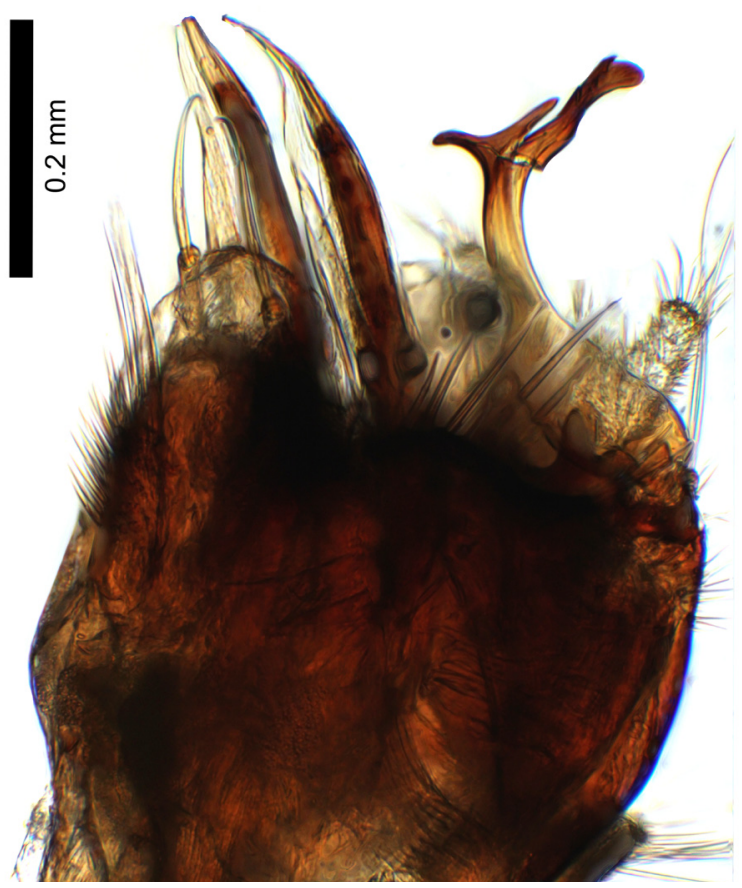

Fig. 4. Lateral view of the male genitalia of a specimen of L. graeca from Bulgaria: Alibotush Mts, Kalimantsi Village, St Iliya Peak, N 41.46001; E 23.49058, 440-510 m, iv.2003, tree traps, leg. M. Langourov, S. Lazarov.

41.76257; E 23.16916, altitude: $203-400 \mathrm{~m}$, collecting period: iv.2003, Malaise trap: $25 \hat{\jmath} \widehat{\partial}, 5$ $\phi$, , leg. M. Langourov; Struma River Valley, $2 \mathrm{~km}$ south of Kamenitsa Village, geographic coordinates: N 41.63816; E 23.17005, altitude: $170-240 \mathrm{~m}$, collecting period: x.2002, pitfall traps: 1 q, leg. M. Langourov.

The species is described from Bulgaria, Western Balkan Range, Vrachanska Planina, Ledenika (Bechev, 1988). Until now, it has been known only from its type locality and another one in Greece (Kurina, 2004). Balkan endemic. Based on the present observations, a wider range of the species could be expected.

\section{Leia graeca Bechev, 1997}

Material examined: Bulgaria: Kresna Gorge, 2 $\mathrm{km}$ south of Stara Kresna Village, N 41.76257; E 23.16916, 203-400 m, collecting period: iv.2003, Malaise trap: 6 $\widehat{\partial}, 6$ 우, leg. M. Langourov; Struma River Valley, $2 \mathrm{~km}$ south of Kamenitsa Village, $\mathrm{N}$ 41.63816; E 23.17005, 170-240 m, collecting period: 


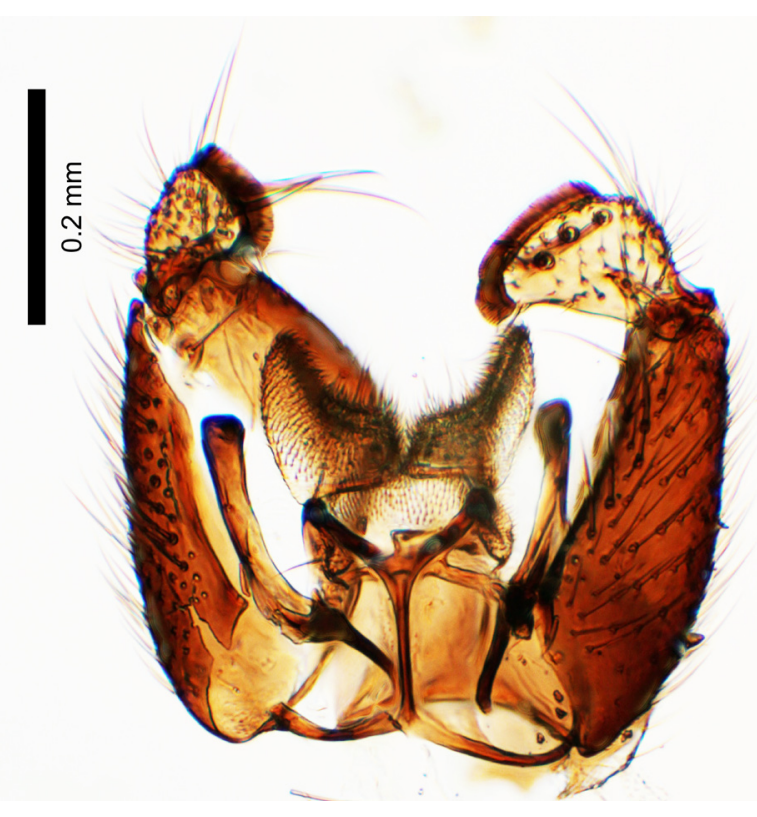

Fig. 5. Dorsal view of the male genitalia of a specimen of A. flavohalterata from Bulgaria: Kresna Gorge, Tisata Reserve, N 41.76691; E 23.15095, 146 m, v.2019, tree traps, leg. A. Pavlova.

iv.2003, tree traps: 1 ô, 2 qq, leg. M. Langourov; Alibotush Mts, Kalimantsi Village, St Iliya Peak, N 41.46001; E 23.49058, 440-510 m, collecting period: iv.2003, tree traps: $16 \hat{\delta} \widehat{\delta}, 4$ q $ᄋ$, leg. M. Langourov, S. Lazarov.

This is the first record of the species in Bulgaria. The species is known up to now with several localities from Greece (Bechev, 1997; Chandler et al., 2005). Balkan endemic species. Photo of lateral view of the male genitalia of the Bulgarian specimen is presented on figure 4. Unfortunately, part of gonostyle is a bit broken but it is still visible that is forked.

\section{Subfamily Sciophilinae}

\section{Azana (Azana) flavohalterata Strobl, 1909}

Azana (Azana) bulgarense Coher, 1995: 87, plate 2 (male terminalia), syn. nov. Type. Holotype male, in the collection of the Department of Zoology, University of Plovdiv, Bulgaria: "Bulgaria: Strandzha Mt., Voden, 27/7/89, D. Bechev".

Material examined: Bulgaria: Kresna Gorge, Tisata Reserve, N 41.76691; E 23.15095, 146 m, col- lecting period: v.2019, tree traps: 1 Oे, 3 우; pitfall

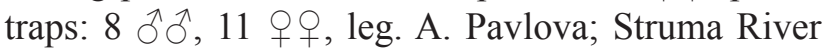
Valley, $2 \mathrm{~km}$ south of Kamenitsa Village, N 41.63816; E 23.17005, 170-240 m, collecting period: x.2019, tree traps: 1 ô, leg. A. Pavlova.

Widespread in the Mediterranean region, recorded in Spain, Cyprus, Greece (Thessaly, Crete, Samos, Paxos, Milos) and Israel (Chandler, 1994; Chandler \& Ribeiro, 1995; Chandler \& Blasco-Zumeta, 2001; Kurina, 2004). In Bulgaria, until now it is reported from a single locality - the type locality of $A$. bulgarense (Strandzha Mts). The unique male is described as a new species under the name Azana (Azana) bulgarense by Coher (1995). According to Chandler \& Blasco-Zumeta (2001), the genitalia that Coher (1995) had figured under the name bulgarense seems identical with Azana (A.) flavohalterata. We found no structural difference in the male genitalia from typical Azana (A.) flavohalterata has been found (plate 2 in Coher, 1995; fig. 48 in Chandler \& Blasco-Zumeta, 2001 and Fig. 5). Therefore, we concluded them to be conspecific and we proposed a new synonymy. The female specimens were associated with the male ones.

\section{Acknowledgments}

The author wants to thank to the colleagues in the National Museum of Natural History, Sofia for the possibility of studying material collected during the abovecited project. A special thank goes also to S. Abadjiev, who kindly provided the map layers. The author is grateful to D. Bechev for the valuable comments on the early version of the manuscript.

\section{References}

Bechev D. 1988 Two New Species of Mycetophilidae from Bulgaria (Insecta, Diptera). Reichenbachia, Staatliches Museum für Tierkunde Dresden 25 (38): 185-186.

Bechev D. 1997 Two new species of Mycetophilidae from Greece and the Netherlands (Insecta, Diptera, Nematocera). Spixiana 20 (2): 179-180.

Bechev D. 2006 The fungus gnats of the families Bolitophilidae, Diadocidiidae, Ditomyiidae and Keroplatidae (Diptera: Sciaroidea) of Bulgaria. Scientific studies of the University of Plovdiv "Paisii Hilendarski”, Biology, Animalia 42: 21-83. 
Bechev D. 2010 On the family Mycetophilidae (Insecta: Diptera) in Bulgaria. ZooNotes, Supplement 1: 1-72.

Bechev D., Pavlova A. 2012 Greenomyia tomovi sp. n. from Bulgaria (Diptera: Mycetophilidae: Leiinae) and a key to the Palaearctic species of the genus. Acta zoologica bulgarica 64 (2): 109-111.

Bechev D., Pavlova A. 2016 Fungus gnats (Diptera: Bolitophilidae, Diadocidiidae, Ditomyiidae, Keroplatidae and Mycetophiliade) of Vrachanska Planina Mountains. In: Bechev D., Georgiev D. (eds) Faunistic diversity of Vrachanski Balkan Nature Park. ZooNotes, Supplement 3, Plovdiv University Press, Plovdiv, 169-179.

Chandler P. 1994 The fungus gnats of Israel (Diptera: Sciaroidea, excluding Sciaridae). Israel Journal of Entomology 28: 1-100.

Chandler P., Blasco-Zumeta J. 2001 The fungus gnats (Diptera, Bolitophilidae, Keroplatidae and Mycetophilidae) of the Monegros region (Zaragoza, Spain) and five other new European species of Pyratula Edwards and Sciophila Meigen. ZAPATERI: Revista aragonesa de entomología 9: 1-24.

Chandler P., Ribeiro E. 1995 The Sciaroidea (Diptera) (excluding Sciaridae) of the Atlantic islands (Canary Islands, Madeira and the Azores). Boletim do Museu Municipal do Funchal (História Natural), Supplement 3: 1-170.

Chandler P., Bechev D., Caspers N. 2005 The fungus gnats (Diptera: Bolitophilidae, Diadocidiidae, Ditomyiidae, Keroplatidae and Mycetophilidae) of Greece, its islands and Cyprus. Studia dipterologica 12 (2): 255-314.

Coher E. 1995 A contribution to a revision of the genus Azana Walker, 1856 (Insecta: Diptera: Mycetophilidae: Sciophilinae). Reichenbachia, Staatliches Museum für Tierkunde Dresden 31 (17): 83-91.

Gussev C. 2015 Shrubs and low woods of Kermes Oak (Quercus coccifera). In: Biserkov V., Gussev C., Popov V., Hibaum G., Roussakova V., Pandurski I., Uzunov Y., Dimitrov M., Tzonev R., Tsoneva S. (eds) Red Data Book of Bulgaria. Volume 3, Natural Habitats, BAS \& MoEW, Sofia, 254-256.
Kerr P. 2010 New Azana species from Western North America (Diptera: Mycetophilidae). Zootaxa 2397: 1-14.

Kurina O. 2004 Notes on fungus gnats from the East Mediterranean with description of two new species (Diptera: Sciaroidea excl. Sciaridae). Beiträge zur Entomologie 54 (2): 343-355.

Kurina O., Chandler P. 2018 New European records of Ditomyia macroptera Winnertz (Diptera: Ditomyiidae) with notes on its distribution. Biodiversity Data Journal 6: 2-8.

Langourov M. 2001 Faunistichni, ekologichni i zoogeografski prouchvania na semeystvo Phoridae (Diptera, Brachycera) ot Vitosha planina. Unpublished $\mathrm{PhD}$ thesis. Institute of Zoology, Sofia, 1-171. (in Bulgarian)

Langourov M., Simov N. 2006 Study on the biodiversity of model groups animals in communities of Quercus coccifera L. Historia naturalis bulgarica 17: 166. (In Bulgarian)

Langourov M., Ignatov A., Baltadzhiev T. 2012 A new locality of Kermes oak (Quercus coccifera L.) in Bulgaria. Historia naturalis bulgarica 20: 139-142. (In Bulgarian)

Pavlova A. 2020 First study of fungus gnats (Insecta: Diptera: Sciaroidea) in Tisata Reserve (SW Bulgaria). ZooNotes 154: 1-4.

Pavlova A., Stojanova A. (in press) Interesting features of the winter activity of fungus gnats (Diptera: Mycetophilidae) in critically endangered Mediterranean habitats in Bulgaria. Acta zoologica bulgarica, Supplement 15.

Ševčík J. 2006 Docosia rohaceki sp. n. and other interesting records of fungus gnats (Diptera: Mycetophilidae) from Pol'ana Biosphere Reserve (central Slovakia). Časopis Slezského Zemského Muzea Opava (A) 55 (2): 131-134.

Tzonev R., Dimitrov D. 2015 Forests of Grecian juniper (Juniperus excelsa). In: Biserkov V., Gussev C., Popov V., Hibaum G., Roussakova V., Pandurski I., Uzunov Y., Dimitrov M., Tzonev R., Tsoneva S. (eds) Red Data Book of Bulgaria. Volume 3, Natural Habitats, BAS \& MoEW, Sofia, 360-362. 